\title{
Lipid Oxidation Inhibitory Effects and Phenolic Composition of Aqueous Extracts from Medicinal Plants of Colombian Amazonia
}

\author{
Leandro J. Lizcano ${ }^{1}$, María Viloria-Bernal ${ }^{2}$, Francisca Vicente ${ }^{2}$, Luis Angel Berrueta ${ }^{2}$, \\ Blanca Gallo ${ }^{2}$, Magdalena Martínez-Cañamero ${ }^{3}$, Maria Begoña Ruiz-Larrea ${ }^{1} *$ and \\ José Ignacio Ruiz-Sanz ${ }^{1}$
}

1 Department of Physiology, Medicine and Dentistry School, University of the Basque Country UPV/EHU, 48940-Leioa, Spain; E-Mails: lizcanomvz@gmail.com (L.J.L.); joseignacio.ruizs@ehu.es (J.I.R.-S.)

2 Department of Analytical Chemistry, Sciences and Technology School, University of the Basque Country UPV/EHU, 48940-Leioa, Spain; E-Mails: maria.viloria@ehu.es (M.V.-B.); francisca.vicente@ehu.es (F.V.); luisangel.berrueta@ehu.es (L.A.B.); blanca.gallo@ehu.es (B.G.)

3 Department of Health Sciences, Microbiology Area, Experimental Sciences School, University of Jaen, 23071-Jaen, Spain; E-Mail: canamero@ujaen.es

* Author to whom correspondence should be addressed; E-Mail: mbego.ruizlarrea@ehu.es; Tel.: +34-946012829; Fax: +34-946015662.

Received: 1 April 2012; in revised form: 23 April 2012 / Accepted: 2 May 2012 /

Published: 4 May 2012

Abstract: Diverse plants of ethnobotanic interest in Amazonia are commonly used in traditional medicine. We determined the antioxidant potential against lipid peroxidation, the antimicrobial activity, and the polyphenol composition of several Amazonian plants (Brownea rosademonte, Piper glandulosissimum, Piper krukoffii, Piper putumayoense, Solanum grandiflorum, and Vismia baccifera). Extracts from the plant leaf, bark, and stem were prepared as aqueous infusions, as used in folk medicine, and added to rat liver microsomes exposed to iron. The polyphenolic composition was detected by reverse-phase HPLC coupled to diode-array detector and MS/MS analysis. The antimicrobial activity was tested by the spot-on-a-lawn method against several indicator microorganisms. All the extracts inhibited lipid oxidation, except the $P$. glandulosissimum stem. The plant extracts exhibiting high antioxidant potential ( $V$. baccifera and $B$. rosademonte) contained high levels of flavanols (particularly, catechin and epicatechin). By contrast, S. grandiflorum leaf, which exhibited very low antioxidant activity, was rich in hydroxycinnamic acids. None of the extracts showed antimicrobial activity. This study demonstrates for the first 
time the presence of bioactive polyphenolic compounds in several Amazonian plants, and highlights the importance of flavanols as major phenolic contributors to antioxidant activity.

Keywords: polyphenols; lipid peroxidation; liver microsomes; HPLC-DAD-MS/MS; Amazonian plants

\section{Introduction}

Medicinal plants are sources of therapeutic compounds. Thus, most of the actual drugs derive from plants, which are natural resources in indigenous communities. For instance, the alkaloids, atropine and scopolamine were isolated from plants of the Solanum genus, and are commonly used in medical applications as antispasmodic, sedative, and anticholinergic agents [1,2]. Among the natural effects of plant extracts, many actions, such as vasodilator, antimicrobial, sedative, anti-depressive, anti-pyretic, and anti-inflammatory are highlighted. There is an increasing interest in finding natural bioactive molecules from plants, in order to avoid side effects associated with synthetic drugs. The rainforest in Northwest Amazonia (Colombia, Ecuador, and Peru) represents a large area of ethnobotanical interest [3]. Historically, indigenous communities in these regions have used botanical resources with therapeutic activities [4,5]. In most of the cases, their use is limited to their intake as food after being cooked or as infusions, but other forms, such as maceration and its application to the skin, or vapour inhalation from infusions are also used. The Brownea rosademonte bark is used against snake venom, acting as an anticoagulant, also as a haemostatic against internal bleeding and haemorrhages, as well as against prolonged menstruation [6,7]. The plant species Solanum grandiflorum is widely used for its sedative, relaxant, and anti-spasmodic properties, and also in the treatment of skin infections [8,9]. Several Vismia species have been used against skin diseases, such as dermatitis, herpes, eczemas and wounds [10-12]. Cytotoxic and antiplasmodial [13,14], antiprotozoal [15], anticancer activity [16], HIV-inhibitory [17] and antimicrobial activities [18] were attributed to substances isolated from the Vismia species.

Many of the therapeutic actions of phytochemicals are ascribed to their biologically active polyphenol components, such as flavonoids and phenolic acids, which possess powerful antioxidant activities [19,20]. It is important for pharmacological purposes to screen, analyse, and identify these constituents.

The antioxidant activities, evaluated by the Trolox equivalent antioxidant activity (TEAC) and oxygen radical absorbance capacity (ORAC) assays, of different Amazonian plants prepared as aqueous infusions have been previously described, all the extracts showing different degrees of antioxidant activities. However, most of phytochemicals are multifunctional, and total antioxidant activity based solely on one property, such as their scavenging activity towards artificial radicals, provides no information on what lipid or other substrate is protected.

In the present work, we have assessed the lipid peroxidation inhibitory effects of aqueous extracts of six Amazonian plants, using rat liver microsomes as the lipid source. This lipid model system mimics the physiological target system to be protected. In addition, the phenolic composition of the 
extracts was characterised by reverse phase HPLC coupled to a diode array detector (DAD) and MS/MS analysis.

\section{Results and Discussion}

\subsection{Inhibition of Lipid Peroxidation}

In this work six Amazonian species that had been shown to exert high in vitro antioxidant activities against hydrophilic radicals [21] were selected in order to analyse their protective effect against lipid peroxidation. The bark of $B$. rosademonte and leaves and stems of $P$. glandulosissimum, $P$. krukoffii, $P$. putumayoense, $S$. grandiflorum and $V$. baccifera were prepared as aqueous infusions, as are commonly used in folk medicine. Rat liver microsomes exposed to iron/ascorbate were chosen as an oxidative system because it is close to the in vivo situation where both an aqueous phase and a lipid phase are present. Figure 1 shows the time-course of thiobarbituric acid reactive substances (TBARS) production in liver microsomes without antioxidants.

Figure 1. Time-course of iron-induced lipid peroxidation of rat liver microsomes. Microsomes $(0.5 \mathrm{mg}$ protein $/ \mathrm{mL})$ were incubated with $25 \mu \mathrm{M} \mathrm{FeSO}_{4}$ and $500 \mu \mathrm{M}$ ascorbic acid in $10 \mathrm{mM} \mathrm{KH}_{2} \mathrm{PO}_{4}$, pH 7.4. Each value is the mean of 5 independent assays.

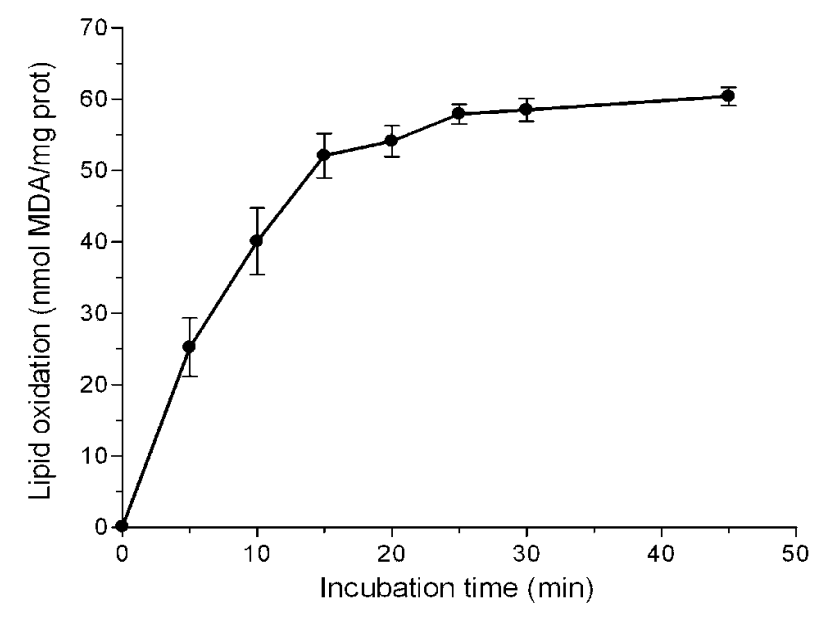

With short incubation periods TBARS levels increased linearly with time, reaching maximum values at near $25 \mathrm{~min}$. A $10 \mathrm{~min}$ incubation period was chosen to study the effects of the extracts. Different volumes of the water infusions were added to the microsome solutions, so that a final 20-80\% inhibition could be detected. Figure 2 shows typical concentration-dependent inhibition curves exhibited by some of the assayed extracts. 
Figure 2. Inhibition of iron-induced microsomal lipid peroxidation by plant extracts. Microsomes $\left(0.8 \mathrm{mg}\right.$ protein/mL) were incubated for $10 \mathrm{~min}$ with $\mathrm{FeSO}_{4} /$ ascorbate $(25$ $\mu \mathrm{M} / 500 \mu \mathrm{M})$ in the presence of increasing quantities of the indicated plant extracts in a 1 $\mathrm{mL}$ final volume. Each value is the mean of at least 3 independent assays.

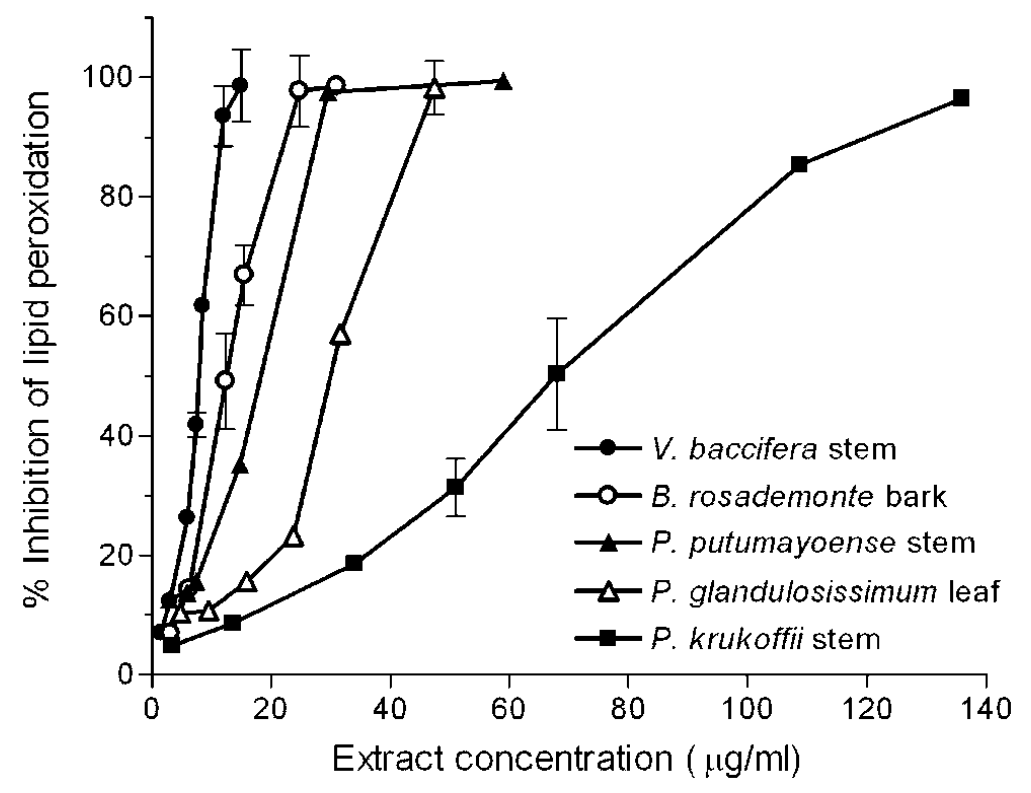

The quantity of extract which inhibited control malondialdehyde (MDA) production by $50 \%$ ( $\mathrm{IC}_{50}$ ) was determined from the curves. Results are summarised in Table 1. For comparative purposes, the $\mathrm{IC}_{50}$ for caffeic acid, catechin, and gallic acid was also measured.

Table 1. Lipid peroxidation half-inhibition values $\left(\mathrm{IC}_{50}\right)$ of plant extracts and reference antioxidants.

\begin{tabular}{|c|c|c|c|c|}
\hline \multirow[b]{2}{*}{ Species } & \multirow[b]{2}{*}{$\begin{array}{l}\text { Plant } \\
\text { Part } \\
\end{array}$} & \multicolumn{3}{|c|}{$\mathrm{IC}_{50}$} \\
\hline & & $\begin{array}{l}\text { Concentration } \\
(\mu \mathrm{g} / \mathrm{mL})\end{array}$ & $\begin{array}{l}\text { Total Phenols } \\
(\mu \mathrm{g} \mathrm{GAE} \text { a } / \mathrm{mL})\end{array}$ & $\begin{array}{l}\text { Total Flavonoids } \\
(\mu \mathrm{g} \mathrm{CE} / \mathrm{mL})\end{array}$ \\
\hline B. rosademonte & bark & 12.4 & 4.9 & 1.6 \\
\hline P. glandulosissimum & leaf & 30.0 & 3.7 & 1.4 \\
\hline P. glandulosissimum & stem & ND & ND & ND \\
\hline P. krukoffii & leaf & 75.0 & 46.3 & 23.9 \\
\hline P. krukoffii & stem & 68.0 & 34.0 & 17.2 \\
\hline P. putumayoense & leaf & 17.9 & 8.7 & 4.5 \\
\hline P. putumayoense & stem & 18.4 & 6.7 & 3.0 \\
\hline S. grandiflorum & leaf & 97.7 & 22.4 & 5.5 \\
\hline S. grandiflorum & stem & 24.1 & 4.5 & 2.0 \\
\hline V. baccifera & leaf & 5.5 & 2.2 & 1.2 \\
\hline V. baccifera & stem & 7.9 & 2.6 & 1.0 \\
\hline Caffeic acid & & 38.0 & & \\
\hline Catechin & & 3.0 & & \\
\hline Gallic acid & & 8.8 & & \\
\hline
\end{tabular}

ND: not detected at the highest concentration used $(240 \mu \mathrm{g}$ extract $/ \mathrm{mL}){ }^{\text {a }}$ GAE, gallic acid equivalents; ${ }^{\mathbf{b}} \mathrm{CE}$, catechin equivalents. 
The order of protection efficacies against lipid peroxidation of the reference antioxidants was catechin > gallic acid > caffeic acid. All the extracts exerted antioxidant effects against lipid peroxidation, except $P$. glandulosissimum stem, which showed no effect at the highest concentration used $(240 \mu \mathrm{g} / \mathrm{mL})$. V. baccifera extracts were the most potent antioxidants against lipid peroxidation, the $\mathrm{IC}_{50}$ values of the leaf $(5.5 \mu \mathrm{g} / \mathrm{mL})$ and stem $(7.9 \mu \mathrm{g} / \mathrm{mL})$ being even lower than that of gallic acid $(8.8 \mu \mathrm{g} / \mathrm{mL})$. B. rosademonte bark also showed a high inhibitory potential in a similar concentration range. $P$. krukoffii leaf and stem presented intermediate protective actions $\left(\mathrm{IC}_{50}\right.$ near $70 \mu \mathrm{g} / \mathrm{mL}$ ), while $S$. grandiflorum leaf was the least potent (near $100 \mu \mathrm{g} / \mathrm{mL}$ ). Thus, using this lipid system, important differences in the behaviour exhibited by the extracts compared with that observed using aqueous free radicals can be highlighted. Lipid peroxidation is a free radical-mediated process, in which oxidative damage is propagated to polyunsaturated fatty acids. It involves lipid-derived radicals, such as alkoxyl and peroxyl radicals. The polarity features of the extract components is a key factor that confers their solubility and ability to access to the lipid phase where the lipoperoxidation process is taking place, thus influencing their capacity to break chain reactions. Antioxidant compounds with high partition coefficients are preferentially distributed to hydrophobic compartments, thus protecting lipids from free radical attack.

\subsection{Antimicrobial Activity}

The antimicrobial activity against several indicator strains (L. monocytogenes, B. cereus, S. aureus, E. coli, and S. enterica) was also tested. No antimicrobial activity was exhibited by any of the aqueous plant extracts (data not shown). Antimicrobial activity against Gram-negative and Gram-positive bacteria of extracts of the Vismia sepcies (V. laurentii) has been reported in the literature [18]. However, in contrast to our conditions, the authors used methanolic extracts to test their effectiveness on the pathogenic agents. In many cases, the water-soluble (aqueous) parts of an extract exhibit no activity or less than the water-insoluble ones [22,23]. To our knowledge this is the first report providing information regarding antimicrobial activity of aqueous extracts of the plants used in this study. The generalized lack of antimicrobial activity in these extracts supports their oral intake since it prevents them from jeopardizing the beneficial autochthonous intestinal microbiota.

\subsection{Polyphenolic Composition by HPLC-DAD and MS/MS Analysis}

The specific polyphenolic composition of the extracts was analysed by HPLC-DAD and MS/MS. To our knowledge, this is the first report showing the presence of an array of polyphenolic compounds in aqueous extracts of these Amazonian species used here. The presence of several families (flavanones, flavonols, hydroxycinnamic acids, hydroxybenzoic acids, flavones, coumarins and flavanols until a polymerization grade of three units) was searched by HPLC-DAD and MS/MS analysis. However, only three of these families (flavanols, flavonols and hydroxycinnamic acids) were found. Figure 3 shows typical chromatograms monitored at 280, 320 and $370 \mathrm{~nm}$ obtained for leaf extracts, where individual components of the three major polyphenol families (flavanols, hydroxycinnamic acids and flavonols) can be identified. 
Figure 3. (a) Piper glandulosissimum leaf extract chromatogram at $320 \mathrm{~nm}$; (b) Piper glandulosissimum leaf extract chromatogram at $370 \mathrm{~nm}$; (c) Vismia baccifera leaf extract chromatogram at $280 \mathrm{~nm}$. CQA, caffeoylquinic acids; deoxyhex, deoxyhexose; epicat, epicatechin; (epi)cat, epicatechin or catechin; hex, hexose; iso, isorhamnetin; kam, kaempferol; $p$-CoQA, $p$-coumaroylquinic acids; pent, pentose; que, quercetin.
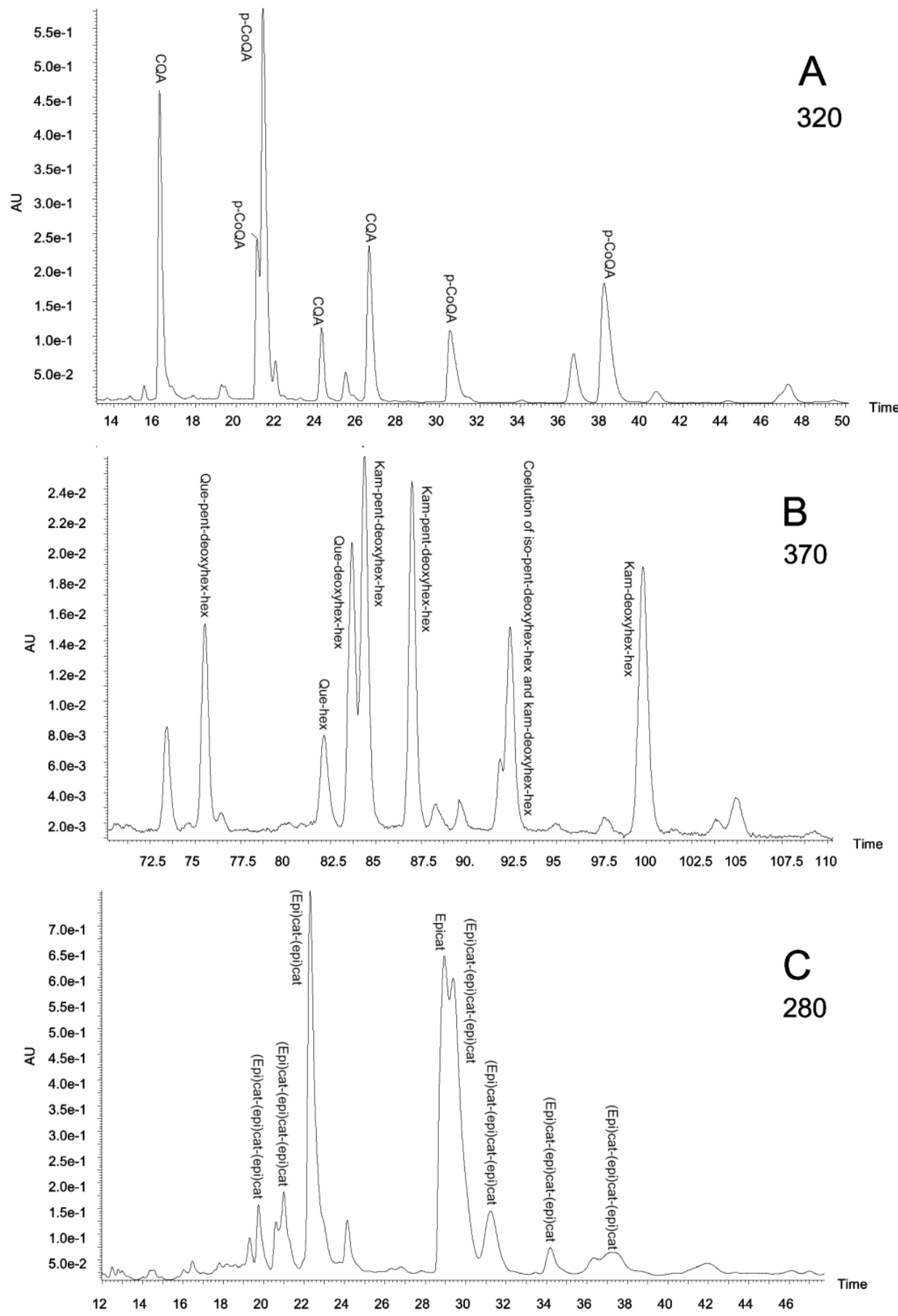

The HPLC retention times, the relative quantities of the individual peaks, and the identified compounds are shown in Table 2. 
Table 2. Relative quantities (area units/mg of plant extract) of major polyphenols and sums of all polyphenols found for each phenolic family and plant species.

\begin{tabular}{|c|c|c|c|c|c|c|c|c|}
\hline $\begin{array}{l}\text { Major Polyphenols and Sums of the } \\
\text { Different Families Found }\end{array}$ & Rt (min) & $\begin{array}{l}\text { B. rosademonte } \\
\text { Bark }\end{array}$ & $\begin{array}{l}\text { P. glandulosissimum } \\
\text { Leaf }\end{array}$ & $\begin{array}{l}\text { P. glandulosissimum } \\
\text { Stem }\end{array}$ & $\begin{array}{l}\text { S. grandiflorum } \\
\text { Leaf }\end{array}$ & $\begin{array}{l}\text { S. grandiflorum } \\
\text { Stem }\end{array}$ & $\begin{array}{l}\text { V. baccifera } \\
\text { Leaf }\end{array}$ & $\begin{array}{l}\text { V. baccifera } \\
\text { Stem }\end{array}$ \\
\hline$\sum \mathrm{FA}$ & & 171730 & 32296 & 7637 & n.d. & n.d. & 1971026 & 257339 \\
\hline (epi)cat-(epi)cat-(epi)cat & 9.10 & n.d. & 9344 & 1369 & n.d. & n.d. & n.d. & n.d. \\
\hline (epi)cat-(epi)cat & 14.85 & 15104 & 3094 & n.d. & n.d. & n.d. & n.d. & n.d. \\
\hline (epi)cat-(epi)cat & 15.87 & 6731 & 4786 & 2630 & n.d. & n.d. & n.d. & n.d. \\
\hline (epi)cat-(epi)cat-(epi)cat & 16.45 & n.d. & n.d. & 1685 & n.d. & n.d. & n.d. & n.d. \\
\hline (epi)cat-(epi)cat & 17.58 & 12219 & n.d. & n.d. & n.d. & n.d. & n.d. & n.d. \\
\hline Cat & 19.37 & 28346 & 9966 & 3225 & n.d. & n.d. & - & - \\
\hline (epi)cat-(epi)cat-(epi)cat & 19.73 & n.d. & n.d. & n.d. & n.d. & n.d. & 50524 & 8592 \\
\hline (epi)cat-(epi)cat-(epi)cat & 20.98 & n.d. & n.d. & n.d. & n.d. & n.d. & 82616 & 14036 \\
\hline (epi)cat-(epi)cat & 22.30 & 45400 & n.d. & n.d. & n.d. & n.d. & 422618 & 64600 \\
\hline Epicat & 28.93 & 48261 & 1285 & 413 & n.d. & n.d. & 463423 & 112225 \\
\hline (epi)cat-(epi)cat-(epi)cat & 29.37 & n.d. & n.d. & n.d. & n.d. & n.d. & 523159 & n.d. \\
\hline (epi)cat-(epi)cat-(epi)cat & 31.22 & n.d. & n.d. & n.d. & n.d. & n.d. & 129118 & 23137 \\
\hline (epi)cat-(epi)cat-(epi)cat & 34.17 & n.d. & n.d. & n.d. & n.d. & n.d. & 41978 & 4828 \\
\hline (epi)cat-(epi)cat-(epi)cat & 37.22 & n.d. & n.d. & n.d. & n.d. & n.d. & 83613 & n.d. \\
\hline (epi)cat-(epi)cat-(epi)cat & 85.17 & n.d. & n.d. & n.d. & n.d. & n.d. & n.d. & 1627 \\
\hline$\sum \mathrm{FVL}$ & & n.d. & 11232 & 967 & 12401 & n.d. & 106166 & 2696 \\
\hline Que-pent-deoxyhex-hex & 75.53 & n.d. & 1045 & 165 & n.d. & n.d. & n.d. & n.d. \\
\hline Kam-deoxyhex-hex & 76.18 & n.d. & n.d. & n.d. & 5605 & n.d. & n.d & n.d. \\
\hline Que-hex & 82.28 & n.d. & n.d. & n.d. & n.d. & n.d. & 23930 & n.d. \\
\hline Que-deoxyhex-hex & 83.73 & n.d. & 1521 & 344 & n.d. & n.d. & 6678 & 1788 \\
\hline Kam-pent-deoxyhex-hex & 84.37 & n.d. & 2016 & n.d. & n.d. & n.d. & n.d. & n.d. \\
\hline Kam-pent-deoxyhex-hex & 87.00 & n.d. & 1771 & 56 & n.d. & n.d. & n.d. & n.d. \\
\hline $\begin{array}{l}\text { Coelution of iso-pent-deoxyhex-hex and } \\
\text { kam-deoxyhex-hex }\end{array}$ & 92.42 & n.d. & 1207 & $123^{\mathrm{a}}$ & n.d. & n.d. & n.d. & n.d. \\
\hline
\end{tabular}


Table 2. Cont.

\begin{tabular}{|c|c|c|c|c|c|c|c|c|}
\hline $\begin{array}{l}\text { Major Polyphenols and Sums of the } \\
\text { Different Families Found }\end{array}$ & Rt (min) & $\begin{array}{l}\text { B. rosademonte } \\
\text { Bark }\end{array}$ & $\begin{array}{l}\text { P. glandulosissimum } \\
\text { Leaf }\end{array}$ & $\begin{array}{l}\text { P. glandulosissimum } \\
\text { Stem }\end{array}$ & $\begin{array}{l}\text { S. grandiflorum } \\
\text { Leaf }\end{array}$ & $\begin{array}{l}\text { S. grandiflorum } \\
\text { Stem }\end{array}$ & $\begin{array}{l}\text { V. baccifera } \\
\text { Leaf }\end{array}$ & $\begin{array}{l}\text { V. baccifera } \\
\text { Stem }\end{array}$ \\
\hline Que-deoxyhex & 96.18 & n.d. & n.d. & n.d. & n.d. & n.d. & 31258 & 908 \\
\hline Kam-hex & 97.28 & n.d. & n.d. & n.d. & n.d. & n.d. & 22859 & n.d. \\
\hline Kam-deoxyhex-hex & 99.78 & n.d. & 1877 & n.d. & n.d. & n.d. & n.d. & n.d. \\
\hline$\sum \mathrm{HCA}$ & & n.d. & 111242 & 4323 & 1140885 & 565630 & 117394 & n.d. \\
\hline CQA & 16.35 & n.d. & 18512 & n.d. & 110605 & 40783 & n.d & n.d. \\
\hline$p$-CoQA & 21.03 & n.d. & 8420 & n.d. & n.d. & n.d. & n.d. & n.d. \\
\hline$p$-CoQA & 21.32 & n.d. & 29335 & 1318 & 11566 & n.d. & n.d & n.d. \\
\hline CQA & 24.13 & n.d. & 4568 & n.d. & 350237 & 239158 & 91738 & n.d. \\
\hline CQA & 26.77 & n.d. & 12856 & n.d. & 112527 & 61954 & n.d & n.d. \\
\hline$p$-CoQA & 30.53 & n.d. & 8222 & 389 & n.d. & n.d. & n.d. & n.d. \\
\hline$p$-CoQA & 38.12 & n.d. & 17518 & 727 & n.d. & n.d. & n.d & n.d. \\
\hline diCQA & 82.88 & n.d. & n.d. & n.d. & 221270 & 94436 & n.d & n.d. \\
\hline diCQA & 84.60 & n.d. & n.d. & n.d. & 180674 & 49423 & n.d & n.d. \\
\hline diCQA & 98.50 & n.d. & n.d. & n.d. & 110713 & 79875 & n.d & n.d. \\
\hline
\end{tabular}

- not determined; n.d. not detected. In P. glandulosisimum stem only iso-pent-desoxihex-hex was found. CQA, caffeoylquinic acids; cat, catechin; deoxyhex, deoxyhexose; diCQA, dicaffeoylquinic acids; epicat, epicatechin; (epi)cat, epicatechin or catechin; FA, flavanols; FVL, flavonols; HCA, hydroxycinnamic acids; hex, hexose; iso, isorhamnetin; kam, kaempferol; $p$-CoQA, $p$-coumaroylquinic acids; pent, pentose; que, quercetin. 
Interestingly, in B. rosademonte bark the only polyphenolic family detected was flavanol, including monomers and dimers. This phenolic species, also including trimers, was also the major component of $V$. baccifera stem, where only two quercetin derived flavonols were found. In contrast, quite a lot of hydroxycinnamic acids were detected in S. grandiflorum, these being the only polyphenolic family in the stem, whereas a few quercetin- and kaempferol-derived flavonols were also found in the leaf extract. Flavanols, flavonols and hydroxycinnamic acids were detected in $V$. baccifera leaf and $P$. glandulosissimum leaf and stem, although in $V$. baccifera leaf only a few hydroxycinnamic (caffeoylquinic) acids were observed.

Different plant organs normally have a different content of polyphenols, being higher in the leaf than in the stem. This is the case with $P$. glandulosissimum, where flavanols, flavonols and hydroxycinnamic acids were found in both parts, leaf and stem, but more compounds were detected in the leaf due to the higher polyphenolic concentration.

In P. krukoffii and P. putumayoense extracts no polyphenols of the type studied were found.

The plant extracts exhibiting high antioxidant potential against lipid peroxidation ( $V$. baccifera and B. rosademonte) contained high levels of flavanols, according to their phenolic characterisation by HPLC; in particular, catechin and epicatechin were the most abundant flavanols (Tables 1 and 2). In the lipid model, the reference antioxidant catechin was found to be highly potent in preventing lipid oxidation, and about 12-fold more efficient than the hydroxycinnamic acid caffeic acid. This behaviour could explain the high antioxidant activity of the above extracts. By contrast, S. grandiflorum leaf, which exhibited very low antioxidant activity, was rich in hydroxycinnamic acids, in particular, ester forms of caffeic acid (caffeoylquinic and dicaffeoylquinic acids). It is interesting to note that the S. grandiflorum stem, in which HPLC analysis demonstrated lower quantities of polyphenols than the leaf, but a similar composition, was able to inhibit lipid peroxidation quite efficiently $\left(\mathrm{IC}_{50}=24 \mu \mathrm{g} / \mathrm{mL}\right)$. These results indicate that additional phenolic species contained in the stem other than those analysed in this study (such as tannins) and/or other non-phenolic components (such as carotenoids and alkaloids) would contribute to the lipid peroxidation inhibitory activity of the stem.

\section{Experimental Section}

\subsection{Chemicals and Standards}

The phenolic standards, catechin and gallic acid were purchased from Sigma-Aldrich®, USA; gentisic acid, procyanidin B1, procyanidin B2, ferulic acid, sinapic acid, quercetin-3-O-galactoside, quercetin-3-O-glucofuranoside, querectin-3- $O$-glucopyranoside, quercetin-3- $O$-rhamnoside, kaempferol-3- $O$-glucoside, kaempferol-3- $O$-rutinoside, kaempferol-7- $O$-neohesperidoside, kaempferol-3-O-robinoside-7- $O$-rhamnoside, isorhamnetin-3-O-glucoside and isorhamnetin-3-O-rutinoside from Extrasynthèse (Genay, France); while siringic acid, (-)-epigallocatechin, (+)-catechin, (-)-epicatechin, 5'-caffeoylquinic acid, caffeic acid, p-coumaric acid and quercetin-3-O-rutinoside were provided by Sigma-Aldrich Chemie (Steinheim, Germany); caffeoyltartaric acid, apigenin-8- $C$-glucoside-4'- $O$-rhamnoside, quercetagetin and kaempferol-3-O-( $\mathrm{p}$-coumaroyl)glucoside, by Chromadex (Santa Ana, CA, USA); and, quercetin dihydrated by Fluka Chemie (Steinheim, Germany). 
Standard stock solutions were prepared in methanol. Dilutions from stock solutions were made in the initial mobile phase.

Methanol (Romil, Chemical Ltd., Heidelberg, Germany) was of HPLC grade. Water was purified on a Milli-Q system from Millipore (Bedford, MA, USA). Glacial acetic acid provided by Merck (Darmstadt, Germany), was of analytical quality. All solvents used were previously filtered through $0.45 \mu \mathrm{m}$ nylon membranes (Lida, Kenosha, WI, USA).

All other reagents used were from the highest purity available.

\subsection{Plant Samples}

Diverse plants of native Amazonian species with known therapeutic actions were collected from the Macagual Research Centre forest in Florencia, Caquetá (Colombia). The plants were selected on the basis of data from their traditional use in Colombian folk medicine. The plants were taxonomically identified by botanical experts and deposited in the Herbarium of the Botanical Garden of Amazonia University-HUAZ (Florencia, Colombia).

The plant samples were processed in the laboratory within a maximum of $24 \mathrm{~h}$ after harvesting. Otherwise, the material was stored under refrigeration at $4{ }^{\circ} \mathrm{C}$.

\subsection{Preparation of Plant Extracts}

Plant extracts were obtained from infusions prepared as generally used in traditional medicine, as described before [21].

\subsection{Inhibition of Lipid Peroxidation}

Male Sprague Dawley rats (180-200 g) were used to isolate liver microsomes. The experimental use of animals and the particular procedure were approved by the Ethical Committee of Animal Welfare (CEBA) of the Institution. Rats were anesthetised and the liver was perfused with $0.9 \% \mathrm{NaCl}$ to completely eliminate blood. Microsomes were obtained by differential centrifugation [24]. The microsomal pellet was resuspended in $150 \mathrm{mM}$ Tris- $\mathrm{HCl}$ buffer, $\mathrm{pH} 7.4$, and frozen in liquid $\mathrm{N}_{2}$ and stored at $-80{ }^{\circ} \mathrm{C}$. The protein content was determined as by Bradford [25], using bovine serum albumin as standard.

Incubations were performed in $150 \mathrm{mM}$ Tris/ $\mathrm{HCl}, \mathrm{pH} 7.4$, and liver microsomes ( $0.8 \mathrm{mg}$ protein) in a final volume of $1 \mathrm{~mL}$. Microsomes were preincubated with the different extracts for $10 \mathrm{~min}$ at $37{ }^{\circ} \mathrm{C}$. Lipid oxidation was initiated by the addition of $200 \mu \mathrm{L} \mathrm{FeSO}_{4}(0.125 \mathrm{mM})$ and ascorbic acid $(0.5 \mathrm{mM})$

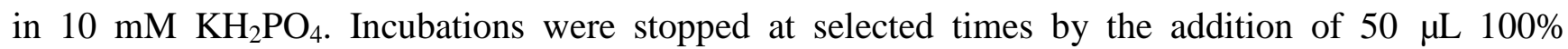
trichloroacetic acid. Samples were maintained $10 \mathrm{~min}$ in ice and then centrifuged $10 \mathrm{~min}$ at $3200 \times \mathrm{g}$. Supernatants were collected. Lipid oxidation was determined by the thiobarbituric acid (TBA) test [26]. Lipid peroxidation was expressed as nmol of malondialdehyde (MDA) per mg of protein, taking into account the molar extinction coefficient of MDA $\left(\varepsilon=156 \mathrm{mM}^{-1} \cdot \mathrm{cm}^{-1}\right)$. Different dilutions of the plant extracts, showing a final percentage inhibition of $20-80 \%$, were used. All the determinations were carried out in duplicate and the experiments were repeated at least three times. Fifty per cent inhibition of lipid peroxidation $\left(\mathrm{IC}_{50}\right)$ was derived from the dose-response curves. The curves were adjusted by 
quadratic regression $\left(R^{2}\right.$ between 0.995 and 1$)$. The lipid peroxidation half maximal inhibition values were expressed as $\mu \mathrm{g}$ of dry weight.

\subsection{Antimicrobial Activity}

The aqueous extracts were individually tested by the spot-on-a-lawn method against a panel of indicator microorganisms including Listeria monocytogenes (CECT 4032), Bacillus cereus (LWL1), Staphylococcus aureus (CECT 828), Escherichia coli (CECT 432), and Salmonella enterica (CECT 916). Indicator bacteria were inoculated (1\%) into soft (0.75\%) Brain Heart Infusion agar (BHI). This was used to overlay Brain Heart Infusion agar (BHA) plates. Then, the aqueous extracts were spotted on the surface of BHA previously inoculated with the indicator strains and after 12-18 hours incubation at $37^{\circ} \mathrm{C}$, the plates were examined for zones of inhibited growth around the spots.

\subsection{HPLC-DAD and MS/MS Analysis}

Chromatographic analyses were performed on a Waters (Milford, USA) Alliance 2695 coupled to a Waters 2996 diode array detector (DAD). A reversed-phase Phenomenex (Torrance, USA) Luna C18 column $(150 \mathrm{~mm} \times 4.6 \mathrm{~mm}$ i.d., particle size $3 \mu \mathrm{m})$ with a Waters Nova-Pack C18 guard column $(10 \mathrm{~mm} \times 3.9 \mathrm{~mm}$ i.d., $4 \mu \mathrm{m})$ was used. The flow rate and column temperature were set to $0.8 \mathrm{~mL} / \mathrm{min}$ and $30{ }^{\circ} \mathrm{C}$, respectively. A gradient program for general polyphenol analysis was employed: the eluents were acetic acid-water (0.5:99.5, v/v) (phase A) and methanol (phase B); initially 0\% B for $2 \mathrm{~min}$, a linear gradient to $15 \% \mathrm{~B}$ at $6 \mathrm{~min}$, held isocratic until $12 \mathrm{~min}$, linear gradient to $20 \% \mathrm{~B}$ at $17 \mathrm{~min}, 20 \% \mathrm{~B}$ constant until $35 \mathrm{~min}$, linear up to $35 \% \mathrm{~B}$ at $90 \mathrm{~min}, 35 \% \mathrm{~B}$ constant until $136 \mathrm{~min}$, and finally linear gradient to $0 \% \mathrm{~B}$ at $145 \mathrm{~min}$.

A $50 \mu \mathrm{L}$ volume of the plant extracts was injected. The chromatograms were monitored at $254 \mathrm{~nm}$ (to study hydroxybenzoic acids), $280 \mathrm{~nm}$ (for flavan-3-ols, condensed tannins, and flavanones), $320 \mathrm{~nm}$ (for hydroxycinnamic acids), $370 \mathrm{~nm}$ (for flavones, flavonols and coumarins); and complete spectral data were recorded in the range 200-600 nm each second.

Mass spectra were obtained on a Micromass (Milford, MA, USA) Quattro Micro triple quadrupole mass spectrometer equipped with a Z-spray ESI source coupled to the exit of DAD. A flow of $70 \mu \mathrm{L} / \mathrm{min}$ from the DAD eluent was directed to the ESI interface using a flow splitter. Nitrogen was used as desolvation gas, at $300{ }^{\circ} \mathrm{C}$ and a flow rate of $450 \mathrm{~L} / \mathrm{h}$, and no cone gas was used. A potential of $3.2 \mathrm{kV}$ was used on the capillary for positive ion mode and $2.6 \mathrm{kV}$ for negative ion mode. The source block temperature was held at $120^{\circ} \mathrm{C}$.

MS spectra, within the 50-1000 $\mathrm{u} \mathrm{m} / \mathrm{z}$ range, were performed at different cone voltages $(\mathrm{CV})$ : in the positive mode 15,30 and $45 \mathrm{~V}$; and in the negative mode 10, 20, 30 and $40 \mathrm{~V}$. MS/MS product ions spectra were recorded using argon as collision gas at $1.5 \times 10^{-3}$ mbar and different collision energies (CE) were assayed in the range $10-35 \mathrm{eV}$.

Individual polyphenols were classified within a polyphenolic family according to their UV-Vis spectra, whereas their identification was performed with the comparison of the MS/MS results with previous studies of standards fragmentation [27]. Peak area obtained from the DAD was used as relative quantitative data. 


\subsection{Statistical Analysis}

Results were expressed as the mean \pm standard deviation (SD). SPSS (version 16.0; SPSS Inc. Chicago, IL, 2007) statistical program was used for data analysis (Pearson's correlation coefficient).

\section{Conclusions}

Our study has demonstrated, for the first time, the presence of bioactive polyphenolic compounds, such as catechin, epicatechin, kaempferol and quercetin, in six Amazonian plants. Most of the aqueous extracts of the plants also exhibited protection against lipid peroxidation. Flavanols, such as catechin and epicatechin, are suggested to largely contribute to the antioxidant activity of the plants, while ester forms of cinnamic acids would have minor contributions. Other components that have not yeen identified also seem to be involved in the lipid peroxidation inhibitory potential of the extracts. These plants may have important roles due to their antioxidant behaviour, and their oral consumption as aqueous infusions is supported for possible prevention of diseases associated with oxidative stress.

\section{Acknowledgements}

We would like to thank MsC. Marco A. Correa-Múnera, University of Amazonia (Florencia, Colombia) and Ricardo Callejas-Posada, from the Biology Institute of the University of Antioquia (Colombia) for the identification and classification of the plants. This work was supported by research grants from the Basque Country Government (Department Education, Universities and Research, reference IT514-10 and reference IT413-10, and DCIT, reference SA-2010/00125), University of the Basque Country UPV/EHU (CLUMBER UFI11/20) and Research Institute of Free Radicals and Metabolism (ERRASMIK/IRALMET, grant to L.J.L.). María Viloria-Bernal thanks University of the Basque Country UPV/EHU. Technical and human support provided by SGIKer (UPV/EHU, MICINN, $\mathrm{GV} / \mathrm{EJ}, \mathrm{ESF}$ ) is gratefully acknowledged.

\section{Conflict of Interest}

The authors declare that they have no conflicts of interest. The authors alone are responsible for the content and writing the paper.

\section{References}

1. Renner, U.D.; Oertel, R.; Kirch, W. Pharmacokinetics and pharmacodynamics in clinical use of scopolamine. Ther. Drug Monit. 2005, 27, 655-665.

2. Kintzel, P.E.; Chase, S.L.; Thomas, W.; Vancamp, D.M.; Clements, E.A. Anticholinergic medications for managing noisy respirations in adult hospice patients. Am. J. Health Syst. Pharm. 2009, 66, 458-464.

3. Vandebroek, I.; van Damme, P.; van Puyvelde, L. ; Arrazola, S. ; de Kimpe, N. A comparison of traditional healers' medicinal plant knowledge in the Bolivian Andes and Amazon. Soc. Sci. Med. 2004, 59, 837-849.

4. Schultes, R.E. Amazonia as a source of new economic plants. Econ. Bot. 1979, 33, 259-266. 
5. Schultes, R.E. Amazonian ethnobotany and the search for new drugs. Ciba Found. Symp. 1994, $185,106-112$.

6. Otero, R.; Nuñez, V.; Barona, J.; Fonnegra, R.; Jimenez, S.L.; Osorio, R.G.; Saldarriaga, M.; Diaz, A. Snakebites and ethnobotany in the northwest region of Colombia Part III: Neutralization of the haemorrhagic effect of Bothrops atrox venom. J. Ethnopharmacol. 2000, 73, 233-241.

7. Nuñez, V.; Otero, R.; Barona, J.; Saldarriaga, M.; Osorio, R.G.; Fonnegra, R.; Jimenez, S.L.; Diaz, A.; Quintana, J.C. Neutralization of the edema-forming, defibrinating and coagulant effects of Bothrops asper venom by extracts of plants used by healers in Colombia. Braz. J. Med. Biol. Res. 2004, 37, 969-977.

8. De Angelis Pereira, M.C.; Carvalho, J.C.; Lima, L.M.; Caputo, L.R.; Ferreira, L.R.; Fiorini, J.E.; Bastos, J.K. Toxicity of a subchronic treatment with hydroalcoholic crude extract from Solanum grandiflorum (Ruiz et Pav) in rats. J. Ethnopharmacol. 2003, 89, 97-99.

9. Sanz-Biset, J.; Campos-de-la-Cruz, J.; Epiquien-Rivera, M.A.; Canigueral, S. A first survey on the medicinal plants of the Chazuta valley (Peruvian Amazon). J. Ethnopharmacol. 2009, $122,333-362$.

10. Lopez, A.; Hudson, J.B.; Towers, G.H.N. Antiviral and antimicrobial activities of Colombian medicinal plants. J. Ethnopharmacol. 2001, 77, 189-196.

11. Mbwambo, Z.H.; Apers, S.; Moshi, M.J.; Kapingu, M.C.; van Miert, S.; Claeys, M.; Brun, R.; Cos, P.; Pieters, L.; Vlietinck, A. Anthranoid compounds with antiprotozoal activity from Vismia orientalis. Planta Med. 2004, 70, 706-710.

12. Nguemeving, J.R.; Azebaze, A.G.B.; Kuete, V.; Carly, N.N.E.; Beng, V.P.; Meyer, M.; Blond, A.; Bodo, B.; Nkengfack, A.E. Laurentixanthones A and B, antimicrobial xanthones from Vismia laurentii. Phytochemistry 2006, 67, 1341-1346.

13. Menan, H.; Banzouzi, J.T.; Hocquette, A.; Pelissier, Y.; Blache, Y.; Kone, M.; Mallie, M.; Assi, L.A.; Valentin, A. Antiplasmodial activity and cytotoxicity of plants used in West African traditional medicine for the treatment of malaria. J. Ethnopharmacol. 2006, 105, 131-136.

14. Suffredini, I.B.; Paciencia, M.L.B.; Varella, A.D.; Younes, R.N. In vitro cytotoxic activity of Brazilian plant extracts against human lung, colon and CNS solid cancers and leukemia. Fitoterapia 2007, 78, 223-226.

15. Estevez, Y.; Castillo, D.; Pisango, M.T.; Arevalo, J.; Rojas, R.; Alban, J.; Deharo, E.; Bourdy, G.; Sauvain, M. Evaluation of the leishmanicidal activity of plants used by Peruvian Chayahuita ethnic group. J. Ethnopharmacol. 2007, 114, 254-259.

16. Hussein, A.A.; Bozzi, B.; Correa, M.; Capson, T.L.; Kursar, T.A.; Coley, P.D.; Solis, P.N.; Gupta, M.P. Bioactive constituents from three Vismia species. J. Nat. Prod. 2003, 66, 858-860.

17. Fuller, R.W.; Westergaard, C.K.; Collins, J.W.; Cardellina, J.H.I.I.; Boyd, M.R. Vismiaphenones D-G, new prenylated benzophenones from Vismia cayennensis. J. Nat. Prod. 1999, 62, 67-69.

18. Kuete, V.; Nguemeving, J.R.; Beng, V.P.; Azebaze, A.G.B.; Etoa, F.X.; Meyer, M.; Bodo, B.; Nkengfack, A.E. Antimicrobial activity of the methanolic extracts and compounds from Vismia laurentii De Wild (Guttiferae). J. Ethnopharmacol. 2007, 109, 372-379.

19. Croft, K.D. The chemistry and biological effects of flavonoids and phenolic acids. Ann. N. $Y$. Acad. Sci. 1998, 854, 435-442.

20. Pietta, P.G. Flavonoids as antioxidants. J. Nat. Prod. 2000, 63, 1035-1042. 
21. Lizcano, L.J.; Bakkali, F.; Ruiz-Larrea, M.B.; Ruiz-Sanz, J.I. Antioxidant activity and polyphenol content of aqueous extracts from Colombian Amazonian plants with medicinal use. Food Chem. 2010, 119, 1566-1570.

22. Ruiz-Larrea, M.B.; Leal, A.M.; Liza, M.; Lacort, M.; de Groot, H. Antioxidant effects of estradiol and 2-hydroxyestradiol on iron-induced lipid peroxidation of rat liver microsomes. Steroids 1994, 59, 383-388.

23. Bradford, M.M. A rapid and sensitive method for the quantitation of microgram quantities of protein utilizing the principle of protein-dye binding. Anal. Biochem. 1976, 72, 248-254.

24. Fee, J.A.; Teitelbaum, H.D. Evidence that superoxide dismutase plays a role in protecting red blood cells against peroxidative hemolysis. Biochem. Biophys. Res. Commun. 1972, 49, 150-158.

25. Abad-Garcia, B.; Berrueta, L.A.; Garmon-Lobato, S.; Gallo, B.; Vicente, F. A general analytical strategy for the characterization of phenolic compounds in fruit juices by high-performance liquid chromatography with diode array detection coupled to electrospray ionization and triple quadrupole mass spectrometry. J. Chromatogr. A 2009, 1216, 5398-5415.

26. Sokmen, A.; Jones, B.M.; Erturk, M. The in vitro antibacterial activity of Turkish medicinal plants. J. Ethnopharmacol. 1999, 67, 79-86.

27. Candan, F.; Unlu, M.; Tepe, B.; Daferera, D.; Polissiou, M.; Sokmen, A.; Akpulat, H.A. Antioxidant and antimicrobial activity of the essential oil and methanol extracts of Achillea millefolium subsp millefolium Afan. (Asteraceae). J. Ethnopharmacol. 2003, 87, 215-220.

(C) 2012 by the authors; licensee MDPI, Basel, Switzerland. This article is an open access article distributed under the terms and conditions of the Creative Commons Attribution license (http://creativecommons.org/licenses/by/3.0/). 